\title{
PENELUSURAN BAKAT DAN MINAT PADA SISWA SMPK HARAPAN BALI
}

\author{
Debora Basaria $^{1}$ dan Kiky D. H. Saraswati ${ }^{1}$ \\ ${ }^{1}$ Program Studi Psikologi, Universitas Tarumanagara Jakarta \\ Email: deborab@fpsi.untar.ac.id \\ Email:kikysaras@gmail.com
}

\begin{abstract}
ABSTRAK
Untuk menghasilkan sumber daya manusia yang unggul di berbagai sektor pekerjaan, tentunya dibutuhkan penelusuran bakat dan minat sejak dini pada seorang individu. Ketika individu memasuki usia remaja, pada umumnya mereka sudah mulai memiliki pemikiran mengenai pekerjaan yang ingin mereka geluti di masa depan. Pendidikan di Indonesia saat ini memiliki kebijakan penjurusan bagi siswa dimulai sejak mereka duduk dibangku sekolah menengah atas (SMA). Terkait dengan hal tersebut, maka penting kiranya dibuat sebuah kegiatan penelusuran bakat dan minat sejak usia sekolah menengah pertama (SMP), dengan harapan mereka akan lebih matang dalam memilih jurusan saat akan memasuki sekolah menengah atas. Kegiatan ini juga dapat mempersiapkan siswa untuk serius menyelesaikan sekolah menengah pertama mereka dengan nilai yang memadai untuk dapat diterima di jurusan yang mereka inginkan. Dari kegiatan yang sudah dilaksanakan diketahui 66\% dari 487 siswa SMPK Harapan Bali memiliki kapasitas intelegensi yang berada dalam kategori rata-rata. Dari penelusuran bakat dan minat didapatkan hasil $23 \%$ dari 487 siswa memiliki minat di area social, 22\% siswa memiliki minat di area artistik dan entrepreneur. 16\% siswa memiliki minat di area investigative, $11 \%$ siswa memiliki minat di area clerical dan 6\% sisanya memiliki minat di area realistic. Dari hasil ini dapat disimpulkan hampir lebih dari 50\% dari total keseluruhan siswa lebih menyukai jurusan yang non-eksakta.
\end{abstract}

Kata kunci: bakat, minat, intelegensi, siswa

\section{PENDAHULUAN}

Tuntutan zaman saat ini memaksa bidang pendidikanmeningkatkan sistem pendidikannyasupaya dapat mencetak generasi muda yang lebih berkualitas. Kurikulum dibuat dengan mengacu pada kebutuhan yang ada di masyarakat, sesuai dengan berkembangnya berbagai macam pekerjaan dan sektor ekonomi yang ada di Indonesia. Sistem penjurusan di sekolahbertujuan untuk mempersiapkan siswa yang unggul pada bidang-bidang tertentu, baik dibidang eksak maupun non eksak. Saat ini di Indonesia, penjurusan pada umumnya akan dimulai pada jenjang pendidikan SMA (kelas 10). Untuk dapat bisa mengikuti pelajaran di setiap penjurusan dengan baik dan juga untuk mengembangkan potensi yang dimiliki siswa, maka penting untuk mengetahui potensi kecerdasan serta bakat dan minat dari siswa.

Di SMPK Harapan Bali,pemeriksaan psikologis hanya dilakukan pada saat siswa kelas 7 dan belum pernah diadakan penelurusan bakat dan minat. Hal tersebut membuat kegiatan ini penting untuk dilakukan dengan melibatkan fakultas psikologi sebagai mitra untuk melakukan asesmen pada siswa-siswi kelas 8 SMPK Harapan Bali. Asesmen tersebut diharapan dapat mempersiapkan siswa sebelum memasuki waktu penjurusan di kelas 10. Kegiatan penelusuran bakat dan minat pada siswa SMP bertujuan untuk mendapatkan gambaran area yang diminati oleh siswa. Sedangkan, manfaat yang diperoleh adalah menjadi data atau informasi bagi pihak sekolah mengenai bakat dan minat siswa untuk dapat dijadikan masukkan dalam kebijakan sekolah. Misalnya, untuk gambaran membuka jumlah kelas penjurusan, merancang kegiatan ekstrakulikuler, dan untuk meningkatkan prestasi sekolah melalui ajang kompetisi. Ruang lingkup dibatasi pada siswa kelas 8 (A-L) SMPK Harapan Bali. 


\section{Intelegensi}

Menurut Wechsler (dalam Soemanto, 2012), inteligensi adalah kemampuan untuk bertindak secara terarah, berpikir secara rasional, dan menghadapi lingkungannya secara efektif. Secara garis besar dapat disimpulkan bahwa inteligensi adalah suatu kemampuan mental yang melibatkan proses berpikir secara rasional. Oleh karena itu, inteligensi tidak dapat diamati secara langsung, melainkan harus disimpulkan dari berbagai tindakan nyata yang merupakan manifestasi dari proses berpikir rasional itu. Senjaya (2010) menyebutkan inteligensi dipengaruhi oleh faktorfaktor sebagai berikut: (a) pengaruh faktor bawaan, (b) pengaruh faktor lingkungan, (c) stabilitas inteligensi dan IQ, (d) pengaruh faktor kematangan, (e) pengaruh faktor pembentukan, (f) minat dan pembawaan yang khas, dan (g) kebebasan. Keseluruhan faktor turut serta menentukan dalam inteligensi seseorang.

\section{Bakat}

Menurut Purwanto (2007), bakat adalah kemampuan dasar seseorang untuk belajar dalam tempo yang relatif pendek dibandingkan orang lain, namun hasilnya justru lebih baik. Bakat merupakan potensi yang dimiliki oleh seseorang sebagai bawaan sejak lahir. Contoh seorang yang berbakat melukis akan lebih cepat mengerjakan pekerjaan lukisnya dibandingkan seseorang yang kurang berbakat. Tujuan mengetahui bakat adalah untuk dapat melakukan diagnosis dan prediksi.Tujuan mengetahui bakat yang pertama adalah untuk melakukan diagnosis. Tes bakat dapat membantu untuk menganalisis permasalahan yang dihadapi testee di masa kini secara lebih cermat. Permasalahan itu baik dalam pendidikan, klinis maupun industri. Dengan bantuan tes bakat ini maka diharapkan psikolog dapat memberikan suatu treatment yang tepat bagi kliennya. Tujuan mengetahui bakat yang kedua untuk prediksi, yaitu untuk memprediksi kemungkinan kesuksesan atau kegagalan seseorang dalam bidang tertentu di masa depan. Manfaat mengenal bakat antara lain: (a) untuk mengetahui potensi diri, (b) untuk merencanakan masa depan, dan (c) untuk menentukan tugas atau kegiatan. Jenis bakat menurut Purwanto (2007), yaitu: (a) bakat umum, merupakan kemampuan yang berupa potensi dasar yang bersifat umum, artinya setiap orang memiliki; dan (b) bakat khusus, merupakan kemampuan yang berupa potensi khusus, artinya tidak semua orang memiliki misalnya bakat seni, pemimpin, penceramah, olahraga.

\section{Minat}

Menurut Hilgar (dalam Slameto, 1998), minat adalah suatu proses yang tetap untuk memperhatikan dan menfokuskan diri pada sesuatu yang diminatinya dengan perasaan senang dan rasa puas. Menurut Maprare (dalam Slameto; 1988), minat adalah suatu perangkat mental yang terdiri dari suatu campuran dari perasaan, harapan, pendirian, prasangka, rasa takut atau kecenderungan lain yang mengarahkan individu kepada suatu pikiran tertentu. Sehingga dapat disimpulkan bahwa minat ialah suatu proses pengembangan dalam mencampurkan seluruh kemampuan yang ada untuk mengarahkan individu kepada suatu kegiatan yang diminatinya.

Jenis-jenis minat berdasarkan tes HOLLAND (RIASEC). Setiap tipe-tipe kepribadian itu dijabarkan ke dalam suatu model teori yang disebut model orientasi (the model orientation). Model orientasi ini merupakan suatu rumpun perilaku perilaku penyesuaian yang khas. Setiap individu memiliki urutan orientasi yang berbeda-beda, dan hal inilah yang menyebabkan mengapa setiap individu mempunyai corak hidup yang berbeda-beda. Berikut merupakan penjabaran model orientasi oleh John L. Holland (t. th). Pertama adalah realistic. Tipe model ini memiliki kecenderungan untuk memilih lapangan kerja yang berorientasi kepada penerapan. Orang model orientasi realistis dalam lingkungan nyatanya selalu ditandai dengan tugas-tugas yang konkrit, fisik, eksplisit yang memberikan tantangan bagi penghuni lingkungan ini. Contoh pekerjaan orang dengan model orientasi ini adalah, operator mesin/radio, sopir truk, petani, penerbang, pengawas 
bangunan, ahli listrik, dan pekerjaan lain yang sejenis. Kedua adalah investigative. Tipe model ini memiliki kecenderungan untuk memilih pekerjaan yang bersifat akademik. Orang model orientasi intelektual dalam lingkungan nyatanya selalu ditandai dengan tugas yang memerlukan berbagai kemampuan abstrak, dan kreatif. Contoh pekerjaan orang dengan model orientasi ini adalah, ahli fisika, ahli biologi, kimia, antropologi, matematika, pekerjaan penelitian, dan pekerjaan lain yang sejenis. Ketiga adalah artistic. Tipe model orientasi ini memiliki kecenderungan berhubungan dengan orang lain secara tidak langsung, bersifat sosial dan sukar menyesuaikan diri.Orang model orientasi artistic ini ditandai dengan berbagai macam tugas dan masalah yang memerlukan interpretasi atau kreasi bentuk-bentuk artistic melalui cita rasa, perasaan dan imajinai. Contoh pekerjaan orang dengan model orientasi ini adalah, ahli musik, ahli drama, pencipta lagu, penyair, dan pekerjaan lain yang sejenis.

Keempat adalah social. Tipe model ini memiliki kecenderungan untuk memilih lapangan pekerjaan yang bersifat membantu orang lain. Contoh pekerjaan orang dengan model orientasi ini adalah, guru, pekerja sosial, konselor, misionari, psikolog klinik, terapis, dan pekerjaan lain yang sejenis. Kelima adalah enterpreneur. Tipe model ini memiliki ciri khas diantaranya menggunakan ketrampilan-ketrampilan berbicara dalam situasi dimana ada kesempatan untuk menguasai orang lain atau mempengaruhi orang lain, menganggap dirinya paling kuat, jantan, mudah untuk mengadakan adaptasi dengan orang lain, menyenangi tugas-tugas sosial yang kabur, perhatian yang besar pada kekuasaan, status dan kepemimpinan, agresif dalam kegiatan lisan. Contoh pekerjaan orang dengan model orientasi ini adalah, pedagang, politikus, manajer pimpinan eksekutif perusahaan, perwakilan dagang, dan pekerjaan lain yang sejenis. Terakhir adalah conventional. Tipe model ini pada umumnya memiliki kecenderungan untuk terhadap kegiatan verbal, ia menyenangi bahasa yang tersusun baik, numerical (angka) yang teratur, menghindari situasi yang kabur, senang mengabdi, mengidentifikasikan diri dengan kekuasaan, memberi nilai yang tinggi terhadap status dan kenyataan materi, mencapai tujuan dengan mengadaptasikan dirinya ketergantungan pada atasan.Contoh pekerjaan orang dengan model orientasi ini adalah, kasir, statistika, pemegang buku, pegawai arsip, pegawai bank, dan pekerjaan lain yang sejenis.

\section{METODE PELAKSANAAN PKM}

Jenis pengabdian masyarakat yang dilakukan adalah asesmen atau tes bakat dan minat yang dilakukan secara klasikal. Klasikal berarti proses pemeriksaan berupa pemberian alat tes bakat dan minat dilakukan secara serentak atau bersama-sama.Peserta dalam kegiatan pengabdian kepada masyarakat ini melibatkan seluruh siswa kelas 8 SMPK Harapan Bali dengan total siswa adalah 487 siswa.

Awalnya, tim pengusul dari Fakultas Psikologi Universitas Tarumanagara melakukan koordinasi dengan pihak sekolah tentang teknis pelaksanaan dan pengambilan data. Pihak sekolah yang diwakili oleh Guru Bidang Kesiswaan dan Kepala Sekolah melakukan koordinasi dengan tim UNTAR pada Selasa,23 Januari 2018 dengan pembicaraan terkait dengan jumlah peserta, tempat, dan waktu pelaksanaan.

Pengabdian kepada masyarakat ini berlangsung pada hari Jumat, 2 Februari 2018 di SMPK Harapan Bali. Kegiatan berlangsung di aula SMPK Harapan Bali yang berada di lantai 4, gedung sekolah SMPK Harapan Bali. Kegiatan PKM diawali pertemuan bersama kepala sekolah dan berbincang-bincang sedikit untuk saling mengenal instansi. Setelah itu, pukul 13.00 - 15.00 WITA dilakukan pengambilan data sesi 1, yang terdiri dari kelas A hingga kelas F. Pukul 15.30 - 17.30 WITA dilakukan pengambilan data sesi 2, kelas G hingga kelas L. 
Acara dimulai dengan memberikan instruksi cara pengerjaan tes. Tes yang pertama kali diberikan adalah tes kecerdasan. Tes kecerdasaan yang digunakan dalam kegiatan ini adalah tes CFIT 2A. Kegiatan administrasi tes yang dipimpin oleh Ibu Debora dan dilaksanakan selama kurang lebih 1 jam. Setelah selesai mengerakan tes kecerdasan, siswa kemudian diberikan instruksi untuk mengerjakan tes bakat dan minat.Tes Minat Bakat yang digunakan adalah tes Holland.

\section{HASIL DAN PEMBAHASAN}

Kegiatan kepada masyarakat ini berlangsung dengan baik. Seluruh siswa terlihat menunjukkan sikap koperatif dalam pengerjaan tes. Terlihat pula sekolah memberikan support terhadap kegiatan ini. Tidak terdapat kendala yang berarti dalam pelaksanaan kegiatan pengabdian masyarakat ini. Penelusuran bakat dan minat pada siswa SMPK Harapan Bali diikuti oleh 53,78\% siswa yang berjenis kelamin laki-laki dan $46,22 \%$ siswa yang berjenis kelamin perempuan. Terlihat bahwa dari total 487 siswa, jumlah siswa laki-laki lebih banyak dibandingkan jumlah siswa perempuan pada siswa kelas 8 SMPK Harapan Bali.

Tabel 1. Gambaran Tingkat Intelegensi secara Umum

\begin{tabular}{lc}
\hline \multicolumn{1}{c}{ Kategori Kecerdasan } & Presentase \\
\hline Intellectual Disability & $1 \%$ \\
Borderline & $3 \%$ \\
Di bawah rata-rata & $22 \%$ \\
Rata-rata & $66 \%$ \\
Di atas rata-rata & $4 \%$ \\
Superior & $3 \%$ \\
Sangat Superior & $1 \%$ \\
\hline Total & $100 \%$ \\
\hline
\end{tabular}

Berdasarkan gambaran tingkat intelegensi secara umum, 66\% siswa kelas 8 SMPK Harapan Bali berada di kategori rata-rata, $22 \%$ berada di kategori di bawah rata-rata, $4 \%$ berada di atas rata-rata, sementara untuk kategori borderline dan kategori superior masing-masing sebanyak 3\%, dan untuk kategori intellectual disability serta sangat superior masing-masing $1 \%$.

Berdasarkan gambaran tingkat inteligensi masing-masing kelas, terlihat bahwa secara umum lebih dari 50\% siswa di setiap kelas memiliki tingkat inteligensi di kategori rata-rata. Berikut merupakan penjabarannya: 41 siswa (72\%) kelas 8A berada di kategori rata-rata, 46 siswa (52\%) kelas 8B berada di kategori rata-rata, 45 siswa (64\%) kelas 8C memiliki kecerdasan rata-rata, 45 siswa $(53 \%)$ di kelas 8D memiliki kecerdasan rata-rata, 45 siswa $(65 \%)$ kelas 8E memiliki kecerdasan rata-rata, 45 siswa $(74 \%)$ kelas $8 \mathrm{~F}$ memiliki kecerdasan rata-rata, 47 siswa (62\%) kelas $8 \mathrm{G}$ memiliki kapasitas kecerdasan yang berada di kategori rata-rata, 46 siswa (50\%) kelas $8 \mathrm{H}$ memiliki kecerdasan rata-rata, 45 siswa $(87 \%)$ kelas $8 \mathrm{I}$ berada di kategori kecerdasan rata-rata, 40 siswa (66\%) kelas $8 \mathrm{~J}$ memiliki kecerdasan rata-rata, 47 siswa (78\%) kelas $8 \mathrm{~K}$ memiliki kecerdasan yang berada pada kategori rata-rata, dan 45 siswa (78\%) kelas 8L memiliki kecerdasan pada kategori rata-rata. 
Tabel 2. Gambaran Hasil Minat Bakat Siswa secara Umum

\begin{tabular}{lc}
\hline \multicolumn{1}{c}{ Minat dan Bakat } & Presentase \\
\hline Realistic & $6 \%$ \\
Investigative & $16 \%$ \\
Artistic & $22 \%$ \\
Social & $23 \%$ \\
Enterpreneur & $22 \%$ \\
Clerical & $11 \%$ \\
\hline Total & $100 \%$ \\
\hline
\end{tabular}

Berdasarkan tabel di atas, terlihat bahwa minat dan bakat Social sebanyak 23\%, Artistic serta Enterpreneur masing-masing 22\%, investigative sebanyak $16 \%$, Clerical sebanyak $11 \%$, dan Realistic sebanyak 6\%.

Tabel 3. Gambaran Hasil Minat Bakat Kelas 8A

\begin{tabular}{lc}
\hline \multicolumn{1}{c}{ Minat dan Bakat } & Presentase \\
\hline Realistic & $2 \%$ \\
Investigative & $19 \%$ \\
Artistic & $19 \%$ \\
Social & $25 \%$ \\
Enterpreneur & $26 \%$ \\
Clerical & $9 \%$ \\
\hline Total & $100 \%$ \\
\hline
\end{tabular}

Gambaran minat dari kelas 8A, diketahui 26\% memiliki minat Enterpreneur sebagai urutan pertama dan Social sebagai urutan kedua.

Tabel 4. Gambaran Hasil Minat Bakat Kelas 8B

\begin{tabular}{lc}
\hline \multicolumn{1}{c}{ Minat dan Bakat } & Presentase \\
\hline Realistic & $11 \%$ \\
Investigative & $15 \%$ \\
Artistic & $18 \%$ \\
Social & $19 \%$ \\
Enterpreneur & $21 \%$ \\
Clerical & $16 \%$ \\
\hline Total & $100 \%$ \\
\hline
\end{tabular}

Hasil penelusuran hasil minat bakat di kelas 8B menunjukkan minat yang rata yaitu Enterpreneur 21\%, Social 19\%, Artistic 18\%, Clerical 16\%, Investigative 15\%, dan Realistic $11 \%$.

Tabel 5. Gambaran Hasil Minat Bakat Kelas 8C

\begin{tabular}{lc}
\hline \multicolumn{1}{c}{ Minat dan Bakat } & Presentase \\
\hline Realistic & $5 \%$ \\
Investigative & $14 \%$ \\
Artistic & $23 \%$ \\
Social & $24 \%$ \\
Enterpreneur & $23 \%$ \\
Clerical & $11 \%$ \\
\hline Total & $100 \%$ \\
\hline
\end{tabular}


Di kelas 8C diketahui penyebaran minat bakat didominasi oleh tiga minat utama yaitu Social $24 \%$, Artistic dan Enterpreneur yang sama-sama $23 \%$.

Tabel 6. Gambaran Hasil Minat Bakat Kelas 8D

\begin{tabular}{lc}
\hline \multicolumn{1}{c}{ Minat dan Bakat } & Presentase \\
\hline Realistic & $8 \%$ \\
Investigative & $11 \%$ \\
Artistic & $22 \%$ \\
Social & $22 \%$ \\
Enterpreneur & $23 \%$ \\
Clerical & $14 \%$ \\
\hline Total & $100 \%$ \\
\hline
\end{tabular}

Penelusuran minat bakat di kelas $8 \mathrm{D}$, menunjukkan penyebaran merata ditiga minat utama dengan Enterpreneur sebanyak 23\%, Artistic dan Social yang sama-sama 22\%.

Tabel 7. Gambaran Hasil Minat Bakat Kelas 8E

\begin{tabular}{lc}
\hline \multicolumn{1}{c}{ Minat dan Bakat } & Presentase \\
\hline Realistic & $7 \%$ \\
Investigative & $13 \%$ \\
Artistic & $24 \%$ \\
Social & $24 \%$ \\
Enterpreneur & $21 \%$ \\
Clerical & $11 \%$ \\
\hline Total & $100 \%$ \\
\hline
\end{tabular}

Penelusuran minat bakat di kelas $8 \mathrm{E}$, menunjukkan penyebaran merata ditiga minat utama dengan Artistic dan Social sama-sama 24\%, dan Enterpreneur $21 \%$.

Tabel 8. Gambaran Hasil Minat Bakat Kelas 8F

\begin{tabular}{lc}
\hline \multicolumn{1}{c}{ Minat dan Bakat } & Presentase \\
\hline Realistic & $3 \%$ \\
Investigative & $17 \%$ \\
Artistic & $25 \%$ \\
Social & $26 \%$ \\
Enterpreneur & $20 \%$ \\
Clerical & $9 \%$ \\
\hline Total & $100 \%$ \\
\hline
\end{tabular}

Hasil penelusuran bakat dan minat di kelas $8 \mathrm{~F}$, menyebar ditiga minat utama yaitu Social sebanyak 26\%, Artisitic 25\%, dan Enterpreneur $20 \%$. 


\begin{tabular}{lc}
\multicolumn{2}{c}{ Tabel 9. Gambaran Hasil Minat Bakat Kelas 8G } \\
\hline \multicolumn{1}{c}{ Minat dan Bakat } & Presentase \\
\hline Realistic & $5 \%$ \\
Investigative & $15 \%$ \\
Artistic & $26 \%$ \\
Social & $22 \%$ \\
Enterpreneur & $22 \%$ \\
Clerical & $10 \%$ \\
\hline Total & $100 \%$ \\
\hline
\end{tabular}

Hasil penelusuran bakat dan minat di kelas $8 \mathrm{G}$, menyebar di tiga minat utama, yaitu Artistic 26\%, Social dan Enterpreneur sama-sama di $22 \%$.

Tabel 10. Gambaran Hasil Minat Bakat Kelas 8H

\begin{tabular}{lc}
\hline \multicolumn{1}{c}{ Minat dan Bakat } & Presentase \\
\hline Realistic & $7 \%$ \\
Investigative & $13 \%$ \\
Artistic & $23 \%$ \\
Social & $21 \%$ \\
Enterpreneur & $25 \%$ \\
Clerical & $11 \%$ \\
\hline Total & $100 \%$ \\
\hline
\end{tabular}

Hasil penelusuran minat dan bakat di kelas $8 \mathrm{H}$, menyebar di tiga minat utama, yaitu Enterpreneur 25\%, dilanjutkan Artistic 23\%, dan Social $21 \%$.

Tabel 11. Gambaran Hasil Minat Bakat Kelas 8I

\begin{tabular}{lc}
\hline \multicolumn{1}{c}{ Minat dan Bakat } & Presentase \\
\hline Realistic & $7 \%$ \\
Investigative & $15 \%$ \\
Artistic & $24 \%$ \\
Social & $23 \%$ \\
Enterpreneur & $21 \%$ \\
Clerical & $10 \%$ \\
\hline Total & $100 \%$ \\
\hline
\end{tabular}

Hasil penelusuran minat dan bakat di kelas 8I, menyebar di tiga minat utama, yaitu Artsitic 24\%, Social 23\%, dan Enterpreneur $21 \%$.

Tabel 12. Gambaran Hasil Minat Bakat Kelas 8J

\begin{tabular}{lc}
\hline \multicolumn{1}{c}{ Minat dan Bakat } & Presentase \\
\hline Realistic & $4 \%$ \\
Investigative & $22 \%$ \\
Artistic & $22 \%$ \\
Social & $24 \%$ \\
Enterpreneur & $19 \%$ \\
Clerical & $9 \%$ \\
\hline Total & $100 \%$ \\
\hline
\end{tabular}


Berdasarkan tabel di atas dapat disimpulkan untuk siswa kelas $8 \mathrm{~J}$ yang berjumlah 40 orang memiliki minat dan bakat paling banyak pada area sebanyak Social $24 \%$, Investigative dan area Artistic sebanyak 22\%, area Enterpreneur sebanyak $19 \%$, area Clerical $9 \%$, dan area Realistic sebanyak $4 \%$.

Tabel 13. Gambaran Hasil Minat Bakat Kelas 8K

\begin{tabular}{lc}
\hline \multicolumn{1}{c}{ Minat dan Bakat } & Presentase \\
\hline Realistic & $5 \%$ \\
Investigative & $22 \%$ \\
Artistic & $21 \%$ \\
Social & $22 \%$ \\
Enterpreneur & $21 \%$ \\
Clerical & $9 \%$ \\
\hline Total & $100 \%$ \\
\hline
\end{tabular}

Berdasarkan tabel di atas dapat disimpulkan untuk siswa kelas $8 \mathrm{~K}$ yang berjumlah 47 orang memiliki minat dan bakat pada area Investigative dan area Social $22 \%$, area Artisitic dan area Enterpreneur $21 \%$, area Clerical 9\%, dan area Realistic sebanyak 5\%.

Tabel 14. Gambaran Hasil Minat Bakat Kelas 8L

\begin{tabular}{lc}
\hline \multicolumn{1}{c}{ Minat dan Bakat } & Presentase \\
\hline Realistic & $5 \%$ \\
Investigative & $17 \%$ \\
Artistic & $21 \%$ \\
Social & $23 \%$ \\
Enterpreneur & $21 \%$ \\
Clerical & $23 \%$ \\
\hline Total & $100 \%$ \\
\hline
\end{tabular}

Berdasarkan tabel di atas dapat disimpulkan, bahwa kelas 8L yang siswanya berjumlah 45 orang, lebih banyak memiliki minat dan bakat area Sosial serta area Clerical sebanyak $23 \%$, area Artistic serta area Enterpreneur sebanyak 21\%, area Investigative sebanyak 17\%, dan area Realistic sebanyak $5 \%$.

\section{KESIMPULAN}

Dari kegiatan yang sudah dilaksanakan dapat disimpulkan 66\% dari 487 siswa SMPK Harapan Bali memiliki kapasitas intelegensi yang berada dalam kategori rata-rata. Diketahui pula, dari penelusuran bakat dan minat mereka didapatkan hasil $23 \%$ dari 487 siswa, memiliki minat di area Social, 22\% merata memiliki minat di area artistik dan entrepreneur. $16 \%$ memiliki minat di area Investigative, $11 \%$ memiliki minat di area Clerical dan $6 \%$ sisanya memiliki minat di area Realistic. Dari hasil ini dapat disimpulkan hampir lebih dari 50\% dari total keseluruhan siswa lebih menyukai jurusan yang non-eksakta. Seluruh pelaksanaan kegiatan PKM juga berjalan dengan baik, tertib, dan lancar. 


\section{Ucapan Terima Kasih}

Berikut ini beberapa ucapan terima kasih kepada beberapa pihak yang telah membantu dan mendukung jalannya PKM yang berjudul "Penelusuran Bakat dan Minat pada Siswa SMPK Harapan Bali”. Ucapan terima kasih yang pertama kami sampaikan kepada DPPM Universitas Tarumanagara yang telah merealisasikan dana untuk mendukung terlaksananya PKM ini. Ucapan terima kasih yang kedua pengusul sampaikan kepada berbagai pihak dari SMPK Harapan Bali yang terdiri dari guru, staff, serta siswa-siswi dalam mendukung dan memberikan kesempatan kepada tim untuk menjalankan PKM yang tentunya sangat berguna. Ucapan terima kasih yang terakhir pengusul sampaikan kepada pihak-pihak lain yang mungkin tidak kami sadari bahwa telah membantu tim dalam melancarkan terlaksananya kegiatan ini. Demikian ucapan terima kasih ini tim sampaikan, semoga terlaksananya PKM dapat berguna atau bermanfaat bagi berbagai pihak yang membutuhkan. Terima kasih.

\section{REFERENSI}

Holland, J. (t. th). Guide to holland codes. Diunduh dari http://www.wiu.edu/advising/docs/Holland_Code.pdf

Purwanto, N. (2007). Psikologi pendidikan. Bandung: PT Remaja Rosdakarya.

Senjaya, S. (2010). Faktor-faktor yang mempengaruhi inteligensi (Artikel). Sutisna.com: Tembolok.

Slameto. (1998). Belajar dan faktor-faktor yang mempengaruhinya. Jakarta: Bina Aksara.

Soemanto, W. (2012). Psikologi pendidikan. Jakarta: Rineka Cipta. 